\title{
Baciuszka, prezbiter czy ksiądz? Poszukiwanie wiodącej denotacji w polskiej terminologii prawosławnej*
}

\author{
ks. Marek Lawreszuk \\ Katedra Teologii Prawosławnej, \\ Uniwersytet w Białymstoku, Polska \\ ORCID: 0000-0001-8051-8106 \\ m.lawreszuk@uwb.edu.pl
}

rev. M. Lawreszuk, The batiuszka, presbyter or priest? Searching for a leading dennotation in polish orthodox terminology, Elpis, 21 2019: 15-19.

\begin{abstract}
The article analyzes the problem of non-standardized and unstructured Orthodox terminology in Polish, in which not only the presence of unordered and untreated connotations of many terms is noticeable, but also a noticeable lack of clearly closed denotations of many terms. The article focuses on examples related to the definition of the second degree of priesthood, present in written sources and colloquial speech. On their basis, we can observe various attempts to solve the problem of the lack of leading denotation. Although some of the postulates were presented in the 1960s, to date, they have not found consistent and widespread acceptance and dissemination.

Streszczenie: Artykuł analizuje problem nieujednoliconej i nieusystematyzowanej terminologii prawosławnej w języku polskim, w której zauważalna jest nie tylko obecność nieuporządkowanych i nieopracowanych konotacji wielu terminów, lecz także zauważalny brak jednoznacznie zamkniętych denotacji wielu terminów. Artykuł skupia się na przykładach związanych z określeniem drugiego stopnia kapłaństwa, obecnych w źródłach pisanych i mowie potocznej. Na ich podstawie możemy zaobserwować różne próby rozwiązania problemu braku wiodącej denotacji. Chociaż niektóre z postulatów zostały przedstawione w latach 60 . XX wieku, to do chwili obecnej, nie znalazły one spójnej i powszechnej akceptacji i upowszechnienia.
\end{abstract}

Keywords: Orthodoxy, terminology, priest, priesthood, denotation

Słowa kluczowe: prawosławie, terminologia, ksiądz, kapłaństwo, denotacja

* Publikacja finansowana w ramach programu Ministra Nauki i Szkolnictwa Wyższego pod nazwą „Narodowy Program Rozwoju Humanistyki” w latach 2017-2022, nr projektu 0083/NPRH5/H11/84/2017.

\section{Wstęp}

Systematyzacja i normatywizacja polskiej terminologii prawosławnej stawia przed badaczami wiele problemów. Jeden $\mathrm{z}$ nich obrazuje zestawienie terminów: baciuszka (batiuszka), ksiądz, prezbiter, które to terminy funkcjonują w polskiej terminologii i pokrywają się zasadniczo znaczeniowo, ale mimo tego, stwarzają problem ze wskazaniem głównego z nich. Pomimo obecności w wielu źródłach pisanych, rozpowszechnieniu w terminologii oficjalnej i potocznej, nie można wskazać głównego $\mathrm{z}$ tych terminów opisującego jeden i ten sam desygnat. Pomimo bogactwa polskiej terminologii religijnej kwestia przyporządkowania terminu wiodącego stanowi, w przypadku języka polskiego prawosławia, problem rozpatrywany w aspekcie teologicznym, konfesyjnym oraz poprawnościowym. Liczba kryteriów, które powinny zostać spełnione sprawia, że część z tych terminów wciąż wymaga dyskusji, negocjacji, opracowania i postulowania rozwiązań.

\section{Polska terminologia prawosławna a polska terminologia religijna}

Polska terminologia prawosławna rozwija się w ścisłej relacji z terminologią Kościoła rzymskokatolickiego, z jednoczesnym wykorzystaniem słownictwa wywodzącego się z języka greckiego i cerkiewnosłowiańskiego. Kościół prawosławny nie wykorzystuje wszystkich określeń funkcjonujących w języku polskim i dotyczących chrześcijaństwa. Na przestrzeni wieków zauważalne jest stworzenie kilku zbiorów specjalistycznej terminologii konfesyjnej i obecnie nawet $\mathrm{w}$ obrębie samego chrześcijaństwa możemy mówić o polskiej terminologii rzymskokatolickiej, prawosławnej czy protestanckiej. Głównym czynnikiem różnicującym stała się specyfika tradycji kultywowanych w różnych wspólnotach chrześcijańskich. Ich tożsamość opiera się zarówno na skoncentrowaniu na odmiennych aspektach wspólnej nauki ewangelicznej, jak i na własnych, odrębnych historycznych ścieżkach, na których tradycja religijna była uzupełniana o kolejne, nowe elementy (często wywodzące się ze specyficznych lokalnych 
uwarunkowań). W przypadku wyodrębnienia terminologii prawosławnej w języku polskim, obok mechanizmów, które towarzyszyły powstaniu innych konfesyjnych zbiorów terminologicznych, ważnym czynnikiem były różnice teologiczne i eklezjalne oraz różnice etymologiczne. Pierwszą przeszkoda w bezkrytycznej adaptacji stały różnice teologiczne i eklezjalne pomiędzy prawosławiem a tradycją rzymskokatolicką. Trudno adaptować lub wykorzystywać terminy, które określają desygnaty nieznane i niezgodne z prawosławną nauką dogmatyczną bądź praktyką życia liturgicznego. Inną przeszkodą na drodze pełnej zbieżności terminologii prawosławnej i rzymskokatolickiej w języku polskim stała się etymologia specjalistycznych terminów. W przypadku tradycji prawosławnej większość z nich wywodzi się z języków greckiego i cerkiewnosłowiańskiego. Terminologia rzymskokatolicka opiera się zaś w znacznym stopniu na łacinie.

Polska terminologia prawosławna funkcjonuje jednak $\mathrm{w}$ nierozerwalnym związku z szerzej rozumianą polską terminologią religijną. $\mathrm{Z}$ tego względu niektóre $\mathrm{z}$ istniejących terminów, które nie odpowiadają całkowicie nauczaniu bądź tradycjom liturgicznym Cerkwi prawosławnej, są przyjmowane z widocznymi oporami, bądź odnajdują swoje odpowiedniki.

Ilustracją przedstawionej wyżej teorii stanie się terminologia określająca chrześcijańskiego duchownego, który w trójstopniowej hierarchii kapłańskiej posiada święcenia drugiego stopnia. Analiza głównych terminów, ich wariantów i synonimów, a także sfrazeologizowanych połączeń pozwoli ukazać rodzące się problemy związane $\mathrm{z}$ jednoznacznością, wzajemnym zrozumieniem i precyzją terminologiczną.

\section{Kilka terminów, jeden desygnat? Prezbiter}

Punktem wyjścia staje się termin określający drugi stopień z trójstopniowej hierarchii kapłańskiej w tradycji chrześcijańskiej (Pseudo-Dionizy Areopagita, 1999, s. 117-122). Oficjalnym terminem opisującym ten desygnat jest prezbiter. Termin ten odnosi się wyłącznie do chrześcijaństwa i posiada kilka zazębiających się ze sobą znaczeń. Współcześnie odnosi się do drugiego stopnia hierarchii kapłańskiej. W tradycji prawosławnej i rzymskokatolickiej związany jest on z łaską sakramentalną udzielaną we wspólnocie wiary. W prawosławiu sakramentalne działanie, określane jako misterium kaptaństwa, precyzyjnie określa termin chirotonia oznaczający dokonanie sakramentu poprzez symboliczne ,włożenie rąk” w trakcie obrzędu. Termin prezbiter posiada jednak także swoją inną konotację, albowiem jest powiązany z organizacją struktur kościelnych wspólnot protestanckich, gdzie oznacza już nie tyle „osobę obdarzoną drugim stopniem hierarchii kapłańskiej” co „osobę kierującą lokalną wspólnotą” (prezbiter, W: Bralczyk J., 2005). W przypadku rozbieżności dotyczącej teologicznej definicji kapłaństwa, hierarchii i sakramentów, mówiąc o prezbiterze możemy więc już mówić jednocześnie o osobie, nad która byt sprawowany misterium kaptaństwa, który stał się osobą duchowną, lub o osobie, która czasowo petni funkcje opiekuna i/lub kierownika lokalnej wspólnoty.

Prawosławna terminologia ściśle definiuje termin jako osobę, która przyjęła misterium kapłaństwa. Definicja „Słownika języka polskiego” (prezbiter, W: Bralczyk J., 2005) nie rejestruje tego znaczenia, postulując ograniczenie znaczenia wyłącznie do tradycji rzymskokatolickiej (znaczenie 1) oraz wskazując znaczenia historyczne (znaczenie 3) oraz administracyjne (znaczenie 2). Opierając się na trójstopniowej hierarchii kapłańskiej należy wpisać ten termin w szereg kolejnych chirotonii: diakona, prezbitera, biskupa. Poszukując więc precyzyjnej definicji należy w niej uwzględnić następujące informacje:

- II stopień święceń (chirotonii). Element spójny dla tradycji rzymskokatolickiej i prawosławnej, w definicji SJP niefortunnie ograniczony do jednej wprowadzeniem warunku ,sprawowania mszy”, który w prawosławiu nie może być spełniony ze względu na nieobecność terminu „msza”.

- Przynależność do stanu kapłańskiego. Element spójny w katolicyzmie i prawosławiu ze względu na zbieżność rozumienia terminu „kapłaństwo”.

- Wczesnochrześcijańskie znaczenie starszego w lokalnej wspólnocie (gminie) religijnej. Dyskusyjne jest jednak wyodrębnienie tego znaczenia, gdyż jest ono zbieżne ze współczesnym rozumieniem II stopnia święceń. Nie stanowi więc odrębnego znaczenia, lecz akcentuje historyczną specyfikę, obecną i aktualną również współcześnie.

- Element zarządzania wspólnotą (gminą) kościelną, jako wyróżnik tradycji protestanckich, również zawiera się we współczesnym rozumieniu II stopnia kapłaństwa, albowiem stanowi jedną z funkcji pełnionych przez prezbiterów (niezależnie od przynależności do Kościoła rzymskokatolickiego, prawosławnego czy wspólnot protestanckich).

\section{Kim jest ksiądz?}

Współczesna słownikowa definicja mówi o „duchownym chrześcijańskim" (ksiądz, W: Drabik, Sobol, 2019). Skromne informacje prowadzą dalej do serii odesłań: duchowny - „odnoszący się do duchowieństwa” lub „ksiądz lub zakonnik" (duchowny, W: Bralczyk J., 2005), co stanowi błędną pętlę i ostatecznie nie wyjaśnia znaczenia terminu. Przyjmuje się jednak, że termin jest także synonimem prezbitera. W „Encyklopedii PWN” pojawia się następująca definicja „pot. określenie duchownego katolickiego, prezbitera, uprawnionego do odprawiania mszy świętej, niższego w hierarchii od biskupa" (ksiądz, W: Encyklopedia PWN, 2016).

Znaczenie tego terminu ewoluuje od historycznego grzecznościowego określenia osoby duchownej, ku potocznemu utożsamieniu z osobą, która przyjęła II stopień święceń kapłańskich. 
W terminologii prawosławnej termin ksiadz funkcjonuje zarówno w sferze potocznej, jak i oficjalnej. Wywodzi się ono od słów władca (kniaź od staropol. kniądz) i nie jest związane $\mathrm{z}$ historycznym rozwojem terminologii prawosławnej. Od końca XIV w. funkcjonuje w polszczyźnie jako tytuł grzecznościowy w odniesieniu do osób duchownych, a nie władców świeckich (Długosz-Kurczabowa, 2016). Prawosławna terminologia rejestruje ten termin w oparciu o współczesną polszczyznę, nadając mu dwa znaczenia: oficjalne - dotyczące całości duchowieństwa i potoczne - ograniczające znaczenie do prezbitera (Kostiuczuk, Tofiluk, Ławreszuk i inni, 2016, s. 25-26).

Innym terminem określającym II stopień hierarchii kościelnej jest kapłan. Niestety jest to również termin wieloznaczny a tym samym nieprecyzyjny. W przedmowie polskiego przekładu dzieła Pseudo-Dionizego Areopagity czytamy o porządku hierarchii kościelnej, w której do grupy duchowieństwo zaliczamy biskupów (hierarchów), kapłanów i diakonów (Pseudo-Dionizy Areopagita, 1999, s. 37). Kapłan jest tu rozumiany jako prezbiter. Problem pojawia się przy stosowaniu nieprecyzyjnych w tym znaczeniu połączeń święcenia kaptańskie, stan kapłański, czy stosowania tego terminu $\mathrm{w}$ innych przypadkach. Zauważalna jest denotacja, która wiąże go z prezbiterem lub wskazuje jako synonim terminu duchowny, tj. do całej grupy duchowieństwa.

Wiążąc terminy ksiądz i prezbiter należy więc wskazać na jedynie potoczną synominiczność $\mathrm{z}$ jednoczesnym zdefiniowaniem księdza jako „tytułu grzecznościowego w odniesieniu do osób duchownych". Jedynie w oparciu o taką definicję poprawne będą połączenia wyrazowe typu ksiadz biskup, ksiądz prezbiter bądź ksiądz diakon (jak również funkcjonujące głównie w terminologii rzymskokatolickiej połączenia: ksiadz lektor, ksiadz kardynat, ksiądz dziekan itp.).

\section{Ksiądz a ojciec}

W terminologii prawosławnej często pojawia się termin ojciec. Nawiązuje on do posługi kapłana jako opiekuna wspólnoty parafialnej i dawnej praktyki określania prezbitera jako abba lub papas (ojciec). W przeciwieństwie do terminologii rzymskokatolickiej, gdzie rzeczownik ojciec jest zwyczajową formą tytularną stosowaną wobec zakonników, prawosławna terminologia nie odnosi go wyłącznie do prezbiterów, którzy są mnichami. Często rejestrowane jest występowanie tego terminu w znaczeniu zbliżonym do jednej z definicji księdza, tj. tytułu grzecznościowego w odniesieniu do osób duchownych. Historyczna kontynuacja tradycji eklezjalnej sugeruje użycie terminu ojciec, który jest bardziej odpowiedni niż przyjęty z kultury zachodnioeuropejskiej termin ksiądz.

Aktualnie dość równorzędnie funkcjonują w prawosławnej polskiej terminologii zwyczajowe zwroty prosze księdza oraz proszę ojca.

W prawosławnej tradycji prezbiter może być nazywany ojcem niezależnie od tego, czy przynależy do tzw. białego duchowieństwa, tzn. jest kapłanem, który wstąpił wcześniej w związek małżeński, czy też jest mnichem. Kompletna tytulatura mnichów wykracza poza ramki niniejszego opracowania, natomiast jeśli mówimy o mnichu prezbiterze, to prawosławna terminologia posiada oficjalny termin hieromnich (Ławreszuk, 2014, s. 456). Jeśli dodatkowo mnich prezbiter uzyskuje kolejne tytuły, może być określany jako: igumen (wariant fonetyczny ihumen), archimandryta, schihieromnich. Kolejne terminy wskazują na mnicha prezbitera, który jednak wyodrębnia się poprzez zakres swoich obowiązków czy pełnione funkcje. Termin igumen $\mathrm{w}$ tradycji słowiańskiej będzie posiadał dwa znaczenia: a) hieromnicha (historycznie również mnich bez święceń), który przewodniczy wspólnocie monasterskiej lub b) jest hieromnichem $\mathrm{z}$ wieloletnim doświadczeniem i został uhonorowany tytułem igumena. Pierwotnie był to termin oznaczający pierwszego (gr. protos) mnicha w monasterze (Aghiorgoussis, 1999, s. 141). Określenie archimandryta w tradycji słowiańskiej ma podobne znaczenia co igumen z tym, że jest to termin wskazujący na wyższy stopień hierarchiczny (archimandryta może się stać długoletni igumen). W tradycji greckiej tytuł archimandryty nie zawsze jest związany z przewodnictwem we wspólnocie monastycznej i często bywa nagrodą za długoletnią i ofiarną służbę hieromnicha. Schihieromnich określa mnicha prezbitera, który w życiu duchowym przyjął postrzyżyny w wielka schimę.

Wobec wszystkich wariantów mnichów prezbiterów zwyczajowym zwrotem jest prosze ojca, chociaż w przypadku igumenów wykorzystywane są również zapożyczenia z języka greckiego lub cerkiewnosłowiańskiego, m.in. geronda lub abbo.

\section{Zróżnicowanie $\mathbf{w}$ terminologii cerkiewnosłowiańskiej}

W polskiej tradycji cerkiewnej w XX wieku pojawiło się zróżnicowanie na protojereja i protoprezbitera. Oba określenia są synonimami i wywodzą się z gr. $\pi \rho \varepsilon \sigma \beta \dot{v} \tau \varepsilon \rho o \varsigma$

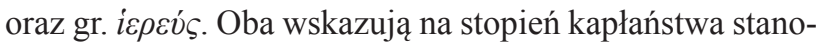
wiący wariant, rozwinięcie stopnia prezbitera. Protoprezbiter lub protojerej to określania duchownych (prezbiterów), którzy za szczególne osiągnięcia, są przez biskupów podnoszeni do nowej godności. Nie są to dodatkowe stopnie hierarchiczne, lecz bardziej zróżnicowanie w ramach prezbiteriatu. Tradycja słowiańska dodatkowo próbuje zróżnicować nagrodę protoprezbitera i protojereja. W Rosyjskiej Cerkwi Prawosławnej prezbiter może uzyskać nagrodę protojereja, a później, jako zwieńczenie posługi i uhonorowanie aktywności i zaangażowania, nagrodę protoprezbitera, która jest określana jako najwyższa nagroda drugiego stopnia kapłaństwa. Od 1890 roku tytułem protoprezbitera byli nagradzani proboszczowie moskiewskich soborów, naczelni kapelani wojsk lądowych i floty (Kostiuczuk, Tofiluk, Ławreszuk i inni, 2016, s. 25-26). W historii Kościoła prawosławnego w Polsce w XX wieku tytuł protoprezbitera nadawano szczególnie zasłużonym duchownym. Pojawiło się również stopniowanie na protoprezbitera 
oraz arcyprezbitera (wariant archiprezbiter). Pomimo tego zróżnicowania, istniejącego w zasadzie wyłącznie w tradycji słowiańskiej (rosyjskiej), księgi liturgiczne wskazują tylko na jeden obrzęd podniesienia do godności prezbitera, niezależnie, jak będzie on określany: pierwszy prezbiter (protoprezbiter), czy pierwszy kapłan (protojerej).

Ponieważ księgi liturgiczne wprowadzają w praktykę Kościoła lokalnego jeden obrzęd podniesienia do godności, należy przyjąć, że określenia mogą być traktowane synonimicznie. Ewentualnie na podstawie historycznych świadectw XIX i XX wieku, należy uznać jeden termin określający ,podniesienie do godności”, tj. regulowany tradycją liturgiczną i obrzędem sprawowanym przez biskupa, natomiast drugi - podobnie jak wiele innych historycznych i lokalnych określeń (np. protosingel) - traktować jako tytuł honorowy (Archijeratikon, 2011, s. 132). Rozwiązaniem może być również kanoniczna korekta przepisów cerkiewnych, która pozwoli ujednolicić praktykę stosowania dodatkowych, honorowych tytułów godności cerkiewnych.

W polskiej terminologii prawosławnej dokonywano już pierwszych prób systematyzacji tych dwóch terminów. W źródłach pisanych niekiedy pojawiły się próby adaptacji terminów rzymskokatolickich, m.in. księdza kanonika, prałata, infułata. Próby te nie zakończyły się sukcesem.

Problem uwidacznia się w oficjalnie stosowanych w polskiej terminologii cerkiewnej połączeniach. Oficjalne dokumenty mówią o księdzu protojereju (rzadziej ksiadz protoprezbiter) - ugruntowany skrót ks. prot. Połączenie to traktuje termin ksiądz w znaczeniu grzecznościowego określenia, natomiast precyzyjne wskazanie kryje się $\mathrm{w}$ terminie protojerej lub protoprezbiter. Jeśli w tych połączeniach termin ksiądz traktować jako synonim prezbitera, będą one obarczone błędem. W takim przypadku ich rozwinięcie oznaczać będzie ksiądz pierwszy ksiądz!

\section{Inne dopuszczalne określenia}

Słowniki i opracowania wskazują na terminy, które są uznawane za synonimy prezbitera. To terminy batiuszka, ojciec, ojczulek, abba, papas. Nie wszystkie są jednakowo rozpowszechnione w polskiej terminologii religijnej. Mają one charakter potoczny i stanowią raczej tradycyjne, familiarne zwroty używane przez wiernych w stosunku do prezbitera.

\section{Wnioski}

Na przykładzie terminów określający II stopień kapłaństwa zauważamy, że uporządkowanie terminologiczne musi uwzględniać:
- różnice pomiędzy dominującą w języku polskim terminologią opartą na doktrynie rzymskokatolickiej a nauczaniem prawosławnym,

- zróżnicowanie w rozumieniu terminów w samej Cerkwi prawosławnej, w obrębie tradycji językowych, kulturowych czy obecnie istniejących strukturach administracyjnych,

- zróżnicowanie na terminologię oficjalną i potoczną.

Nawet na podstawie jednego $\mathrm{z}$ bardziej zrozumiałych i rozpowszechnionych terminów, możemy zaobserwować, że precyzja i ich czytelność wymaga uporządkowania, precyzyjnego określenia zakresu i przyporządkowania kwalifikatorów.

Propozycja rozwiązania wskazanych wyżej problemów związanych z nazewnictwem duchownych prawosławnych powinna uwzględnić następujące postulaty:

1. Precyzyjne zdefiniowanie znaczenia terminu ksiadz, jako a) duchownego, który poprzez chirotonię ( $\mathrm{tj}$. święcenia) otrzymał drugi stopień kapłaństwa, b) tytułu grzecznościowego w odniesieniu od osób duchownych.

2. Przyporządkowanie synonimów terminu ksiądz z uwzględnieniem znaczeń potocznych (batiuszka), hyperonimów oraz wskazanie form niepoprawnych (w ujęciu prawosławnej terminologii).

3. Zdefiniowanie i opatrzenie kwalifikatorem terminu batiuszka. Definicja powinna uwzględniać potoczny charakter terminu i precyzyjnie wskazać na drugi stopień hierarchii duchowieństwa prawosławnego. Batiuszka należałoby określić prezbitera, z jednoczesnym wskazaniem, że jest to także tradycyjny familiarny zwrot używany przez wiernych w stosunku do prezbitera.

4. Przyporządkowanie połączeń wyrazowych do terminu ksiądz z uwzględnieniem obu znaczeń: w zn. a) m.in. ksiadz proboszcz, ksiądz mitrat, w zn. b) ksiadz protojerej, ksiadz protoprezbiter, ksiadz biskup itd.

5. Zdefiniować termin prezbiter odwołując się do zn. a) terminu $k s i a d z$.

6. Opracować znaczenie terminu protojerej. W definicji uwzględnić zróżnicowaną praktykę kanoniczną różnych Cerkwi lokalnych.

7. Opracować termin protoprezbiter wskazujący na a) termin protojerej i b) drugie znaczenie obecne głównie w tradycji Cerkwi rosyjskiej.

8. Przedstawić dodatkowe znaczenie terminu ojciec funkcjonujące w terminologii prawosławnej. Wskazać na istniejące różnice pomiędzy polską terminologią rzymskokatolicką a prawosławną. 


\section{Bibliografia}

Prezbiter (2005), W: Bralczyk J., 2005, Stownik 100 tysięcy potrzebnych stów, red. Bralczyk J., wyd. I, Warszawa.

Ksiądz (2019), W: Drabik L., Sobol E., 2019, Słownik języka polskiego $P W N$, Warszawa.

Ksiądz (2016), W: Encyklopedia PWN, Internet: www.encyklopedia.pwn.pl, dostęp 12.02.2018.

Aghiorgoussis, bp Maximos. (1999). Monastycyzm. W: Leśniewski, K., Leśniewska J. (red.). Prawosławie. Światło wiary i zdrój doświadczenia, Lublin: Prawosławna Diecezja Lubelsko-Chełmska. s. 133-142.

Czarnecka, K., Ławreszuk, M. (2018). „Stownik polskiej terminologii prawosławnej" - struktura artykułu hasłowego. W: Elpis. 20. s. 221-230.

Długosz-Kurczabowa, K. (2016), Ksiądz, W: Poradnia Językowa PWN, Internet: http://sjp.pwn.pl/poradnia/haslo/ksiadz; 5712.html, dostęp: 12.02.2016.
Kostiuczuk J., Tofiluk J., Ławreszuk M., Misijuk W., Charkiewicz J., (2016), Specyfika polskiej terminologii prawosławnej, Białystok.

Ławreszuk, M. (2014). Modlitwa wspólnoty. Historyczny rozwój prawosławnej tradycji liturgicznej. Białystok: Wydawnictwo Uniwersytetu w Białymstoku.

Ławreszuk, M. (2018). Polska terminologia prawostawna - analiza stanu obecnego. W: Elpis. 20. s. 159-163.

Pseudo-Dionizy Areopagita. (1999). Pisma teologiczne II. Hierarchia niebiańska. Hierarchia kościelna. Dzielska, M. (tłum.). Kraków: Znak.

Soborowa Komisja Redakcyjna, Pańkowski, J. (red.). (2011). Archijeratikon. (H. Paprocki, thum.). Warszawa: Warszawska Metropolia Prawosławna.

Rozmiar artykułu: 0,6 arkusza wydawniczego 
ISSN 1508-7719

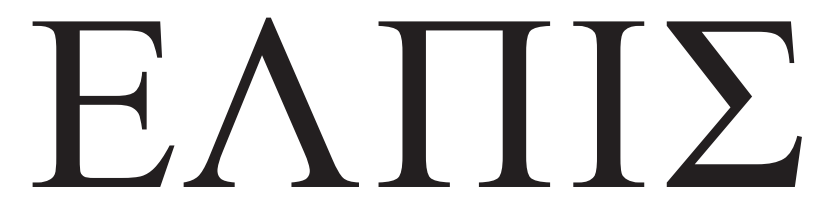

CZASOPISMO TEOLOGICZNE KATEDRY TEOLOGII PRAWOSŁAWNEJ UNIWERSYTETU W BIAŁYMSTOKU

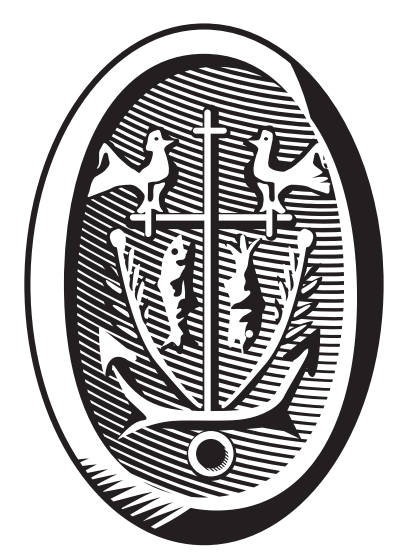

ADRES REDAKCJI

ul. Ludwika Zamenhofa 15, 15-435 Białystok, Polska tel. 85 745-77-80, e-mail: elpis@uwb.edu.pl www.elpis.uwb.edu.pl 